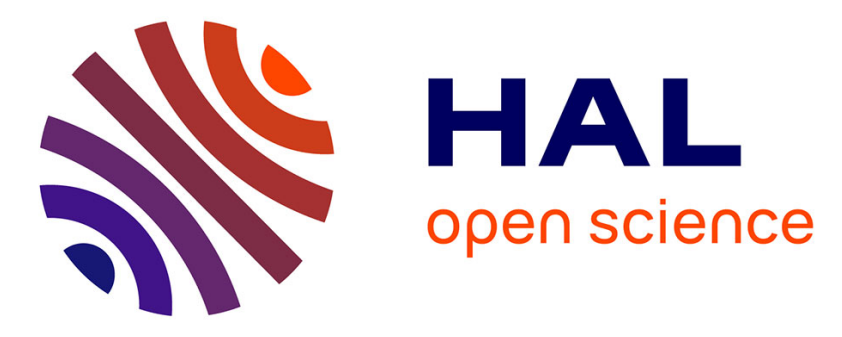

\title{
The provision of amenities by agriculture and rural tourism
}

\author{
Francois Bonnieux, Pierre Rainelli, . Università Degli Studi Di \\ Genova,imperia (ita)
}

\section{To cite this version:}

Francois Bonnieux, Pierre Rainelli,. Università Degli Studi Di Genova,imperia (ita). The provision of amenities by agriculture and rural tourism. Conference on tourism and sustainable development, May 1998, Imperia, Italy. 15 p. hal-01595426

\section{HAL Id: hal-01595426 \\ https://hal.science/hal-01595426}

Submitted on 7 Jun 2020

HAL is a multi-disciplinary open access archive for the deposit and dissemination of scientific research documents, whether they are published or not. The documents may come from teaching and research institutions in France or abroad, or from public or private research centers.
L'archive ouverte pluridisciplinaire HAL, est destinée au dépôt et à la diffusion de documents scientifiques de niveau recherche, publiés ou non, émanant des établissements d'enseignement et de recherche français ou étrangers, des laboratoires publics ou privés.

\section{(ㅇ)(1) $\$$}

Distributed under a Creative Commons Attribution - NonCommercial - NoDerivatives| 4.0 


\title{
THE PROVISION OF AMENITIES BY AGRICULTURE AND RURAL TOURISM
}

\author{
F. Bonnieux, P. Rainelli \\ INRA - Economie Rennes
}

May 1998

\section{Introduction}

The appeal of rural areas for recreation and tourism is directly linked to the increase in income and the urbanisation process. Higher incomes that are accompanied by higher education that increase the awareness of pollution and its harmful effects encourage the demand for environmental quality. The industrialised world, with its urbanisation, explain the appeal for extra-urban environments in the context of a push-pull model of motivation (Pigram, 1993). For urban dwellers, rural environment appears to support various opportunities to experience compensatory alternative surroundings as well as cultural or recreational activities.

Since the beginning of the sixties, as in many developed countries, the economy of rural France has been disadvantaged by structural change and economic dislocation. A double movement lead to a greater regional and on farm specialisation and a greater regional concentration leading to land abandonment .These problems, coupled with a recognition of the potential contribution of tourism to rural economic development, have encouraged an increase in rural tourism. This increase is conditioned by the provision of environmental goods which are only produced through the sustainable development of agriculture.

This paper is organised as follows. The first section provides a set of information examining both the supply side (land use pattern) and the demand side (type of accommodation, number of tourists ). The second section draws attention to the relationships between rural tourism and sustainable agriculture. The third section considers a general framework to assess rural amenities according to their characteristics and how they can be captured by local communities. Finally, the fourth section presents an illustrative example which deals with the economic impact of sportfishing at the regional level.

\section{French rural tourism}

Before examining tourist trade in rural areas, general information about land use patterns in rural areas of France is provided.

\subsection{Land use patterns and rural areas}

Substantial territorial imbalance did not arise in France until the $19^{\text {th }}$ century with industrial development and urbanisation. The city of Paris and its immediate suburbs, which at the time the French Revolution in 1789 accounted for only 2 percent of the French population, saw its share double by the mid-nineties of the 19th century. From then, a considerable growth has occurred in the Paris area at the expense of the rest of France. From 1850 to 1950 , the population drain was specially severe in upland areas. Currently 20 per cent of the French population is concentrated in the Paris area, defined in a broad sense (Ile de France), and nowadays some 80 percent of the population lives in cities.

Land use patterns have gradually settled into a few major categories: urbanised areas, farmland where areas of intensive farming are juxtaposed with marginal rural areas, and forests. A major share of European arable land is found in France. Sixty percent of European farmland is found in France, and accounts for 55\% of the total French

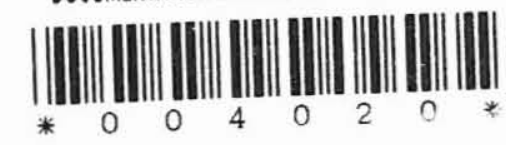


territory. The share of agricultural area under low-intensity farming systems, which provide a large part of rural amenities, is 25 percent (Bignall and Mc. Cracken, 1996). Forests, which covers 28 percent of the territory are steadily rising: the area of agricultural or marginal land given over to forestry is 20000 to 30000 hectares a year. Timber production remains a key objective, though forest management, chiefly in public forests, is now taking account of conservation of wildlife and forest habitats, hunting, tourism and recreation.

The influence of agriculture is highly visible in the quality and the diversity of French landscapes and in the concept of nature as a garden. In the sixties when agriculture became a sector closely linked with input suppliers strengthening the productivity of the soil, a disruption to the generations of farmers previously practising agricultural techniques in harmony with the environment occurred. The associated developments, land consolidation and the abandoning of traditional mixed farming for large-scale growing of cereals and other industrial crops have has an adverse impact on the environment and the preservation of habitats and wildlife.

Over the same period both the rural population and the area under cultivation have fallen, while urban development and afforestation have increased. But local conditions are highly diverse as demonstrated by the mountain areas. France adopted around 1880 a policy to restore plots of mountain and hill land to limit the effects of over-farming. This was due to over population causing extremely harmful erosion in the most fragile areas, with serious consequences on the environment. The population drain to Paris and other large cities which occurred by the end of the nineteenth century and the first half of the twentieth century, was especially severe in upland areas. After the second world war the policy's objective changed direction to ensure the continuation of farming, thereby maintaining a minimum population level and conserving the countryside.

While the upland agricultural exodus has not completely stopped, it continues at a reduced rate. Since 1970 the rate has been virtually the same as the flight from lowland farms. Between 1955 and 1970 the drain on the farm population was 1.5 times faster in mountain areas than elsewhere (cf. table 1).

Table 1. Rate of change in the number of farms (per year)

\begin{tabular}{|l|l|l|}
\hline \multirow{2}{*}{$1955-1976$} & Mountain areas & Non-mountain areas \\
\cline { 2 - 3 } & $-3,6 \%$ & $-2,4 \%$ \\
\hline $1970-1988$ & $-2,6 \%$ & $-2,4 \%$ \\
\hline
\end{tabular}

Source: General census of agriculture.

Nevertheless a closer analysis of mountainous massifs (The Vosges, the Jura, Northern Alps, Southern Alps; Corsica, Northern Massif Central, Southern Massif Central and the Pyrénées) shows a uneven situation for the recent period (cf. table 2). 
Table 2. Demographic and economic characteristics of the French massifs

\begin{tabular}{|c|c|c|c|c|c|c|c|}
\hline & \multicolumn{2}{|c|}{ Population in 1990} & \multirow{2}{*}{$\begin{array}{l}\text { Change } \\
1982-90\end{array}$} & \multicolumn{4}{|c|}{ Jobs within the area, 1990} \\
\hline & Total & $\begin{array}{l}\text { Density (per } \\
\text { sq. } \mathrm{Km} \text {.) }\end{array}$ & & $\begin{array}{l}\text { farming } \\
\% \\
\end{array}$ & $\begin{array}{l}\text { industry } \\
\% \\
\end{array}$ & $\begin{array}{l}\text { construction } \\
\% \\
\end{array}$ & $\begin{array}{l}\text { other } \\
\% \\
\end{array}$ \\
\hline Vosges (All) & 582002 & 79 & -0.01 & 5.0 & 40.6 & 8.0 & 46.4 \\
\hline Jura (All) & 500832 & 51 & 0.88 & 7.9 & 38.0 & 7.0 & 47.1 \\
\hline Northern Alps (All) & 1652890 & 85 & 1.10 & 3.4 & 25.3 & 8.4 & 62.9 \\
\hline Southern Alps (All) & 560981 & 27 & 2.01 & 8.6 & 13.0 & 11.7 & 66.7 \\
\hline Corsica (All) & 250371 & 29 & 0.52 & 8.3 & 7.3 & 11.6 & 72.9 \\
\hline Massif Central (All) & 3700158 & 47 & -0.11 & 11.3 & 24.8 & 7.3 & 56.5 \\
\hline Pyrénées (All) & 479310 & 27 & -0.01 & 14.0 & 17.4 & 8.3 & 60.3 \\
\hline FRANCE & 56610938 & 104 & 0.52 & 6.3 & 23.5 & 7.7 & 62.5 \\
\hline
\end{tabular}

1. Note: "All" includes all areas having broadly to do with mountains, less-favoured areas and areas within the mountain mass that are outside the less-favoured areas.

Source: INSEE, special breakdown of the 1990 population census.

For the period 1982-1990, Table 2 indicates that the overall population of the massifs began to grow again in the eighties. In fact, the growth was heavily concentrated, especially in the Alps, thanks to the rapid development of tourism, mainly winter skiing. Except for the Northern Alps and Vosges, the massifs have a low density, Jura and Massif Central have around 50 inhabitants per square kilometre an even lower density found in the Southern Alps, Corsica and Pyrénées (less than 30). Table 2 shows that farming never exceeds 16 per cent of the total jobs. The major part of the employment is coming from the service sector.

\subsection{Frequency of tourist visits in rural areas}

As in most European countries, France has experienced a decline in mass tourism which benefits rural tourism. The concentration of people in both time and space has had a cumulative effect on scare resources and services such as land, freshwater and sewage treatment. The overcrowding occurring at peak periods leads to traffic congestion, noise air and water pollution. All these factors have had a negative impact on the welfare of the tourists who suffer from the externalities produced by themselves. This internalisation of the disamenities, in part, explains a growing demand for another type of tourism based on countryside resources. Although this is not completely environmentally friendly, it is not yet perceived by tourists and local people as diminishing their enjoyment and appreciation of the rural areas.

The fact that the countryside is increasing in popularity can be observed through the increase in the number of people involved in hiking. Occasional hikers numbered 1.9 million in 1984 and 3.9 five years later, whereas the number of regular hikers grew from 0.84 million to 2.2 million during the same period (IFEN, 1994). Today ,the number of national park visitors is over 2 million a year. A recent survey found that sixty percent of the French population want recreational activities in quiet places.

Statistics on the overnight stays helps to measure the growing importance of rural tourism. French statistics on overnight stays include all travel by people to destinations outside the place they normally live, for any accommodation establishment, (free or not). Travel for business, education or health purposes are excluded. With regard to the total overnight stays, the 1994-1995 survey on vacations taken by the French indicate that countryside destinations are the most attractive. When French people over 15 years old were asked on what place they stayed, $39 \%$ respond they had taken at least on vacation in the countryside. The number of countryside overnight stays is smaller than the average: 4.7 days versus 5.6. From 1991 to 1995 the number of countryside overnight stays grew at twice the rate as the total number of stays: 11.5 percent versus 6 percent, respectively (INRA-INSEE, 1998).

Compared to "classic" tourism, countryside tourism is more specific since free accommodation represents 80 per cent of the total stays versus 60 per cent for the overall holidays. For instance, the share of family visits accounts for 46 per cent of countryside holidays in 1994-1995 versus 34 per cent for overall stays. Another important source of free accommodation is second homes which represent a quarter of countryside overnight stays. The 
main paying accommodation is camping with 8 percent. Farm accommodation and the bed and breakfast operations represent only 4 percent (INRA-INSEE, 1998).

If we turn now to the supply side, we can define the characteristics of accommodation in the countryside .In 1988 , as indicated in table 3 , the total capacity for tourism reached 19 million beds, of which 11 million were located in rural areas (58\% of the total). In rural areas, as well as in the whole country, weekend homes were predominant (over fifty percent), followed by camping (about 20\%). The most specific accommodation of the countryside, rooms in farms (les gites ruraux) and bed and breakfast, accounted for a small percentage: respectively $1.5 \%$ and $0.3 \%$. Nevertheless these two types of accommodations experienced a large increase. Between 1980 and 1988 the supply multiplied by 4 and from 1991 to 1995 increased by an additional $46 \%$.

Table 3. Tourist capacity according to the type of accommodation and the location in 1988

\begin{tabular}{|l|l|l|l|l|l|l|l|l|}
\hline & Hotels & $\begin{array}{l}\text { Bed and } \\
\text { breakfast }\end{array}$ & $\begin{array}{l}\text { Furnished } \\
\text { rooms }\end{array}$ & $\begin{array}{l}\text { Rooms in } \\
\text { farms }\end{array}$ & Camping & $\begin{array}{l}\text { Weekend } \\
\text { homes }\end{array}$ & Other & $\begin{array}{l}\text { Total } \\
\% \mathrm{~N}^{\circ}(000)\end{array}$ \\
\cline { 2 - 8 } Rural areas & 4.3 & 0.3 & 13.1 & 1.5 & 21.0 & 52.0 & 7.9 & $100(11059)$ \\
\hline Total France & 7.8 & 0.3 & 10.8 & 1.5 & 19.0 & 54.4 & 6.7 & $100(19048)$ \\
\hline
\end{tabular}

Source: INRA-INSEE, 1998. Contours et caractères. Portrait social : les campagnes et leurs villes.

Using the last general census of the population additional information on the second homes is available (Table 4). This type of dwelling is very popular in France. It doubled from 1968 to 1990, representing 12,5\% of the total dwellings in 1990. Comparing tables 4 and 3, we have a greater number of second homes in the rural area (56.8\% versus $52.0 \%$ ). This discrepancy is due to the fact that the 1988 results are based on a municipal inventory that used as lightly different classification system.

Table 4 indicates that the increase of second homes is more greater in rural zones than in urban ones. We can also notice than that in the various rural areas, the remote areas experienced the greatest variation. Remote areas represented in 1990 about $30 \%$ of the total French weekend homes.

Table 4. Evolution of the number of weekend homes according to location

\begin{tabular}{|c|c|c|c|c|c|}
\hline & \multicolumn{2}{|l|}{1990} & \multicolumn{3}{|c|}{ Evolution from 1968 to 1990} \\
\hline & $\mathrm{N}^{\circ}(000)$ & $\%$ & $68-75$ & $75-82$ & $82-90$ \\
\hline Rural areas & 1600 & 56,8 & +45 & +40 & +23 \\
\hline of which & & & & & \\
\hline $\begin{array}{l}\text { weakly influenced by metropolitan } \\
\text { areas }\end{array}$ & 473 & 16,8 & +41 & +28 & +16 \\
\hline rural poles and periphery & 285 & 10,1 & +52 & +46 & +29 \\
\hline remote areas & 842 & 29,9 & +46 & +48 & +25 \\
\hline The Whole France & 2819 & 100 & +37 & +35 & +24 \\
\hline
\end{tabular}

Source: INRA-INSEE, 1998. Contours et caractères. Portrait social : les campagnes et leurs villes.

Concerning farms, the 1979 Agricultural census shows that 12300 farms had a tourist activity: riding schools, organisation of private hunts, game breeding, self-catering accommodation, bed and breakfast, nature discovery, etc... . In 1995 this number grew to 16500 with new farmers better educated and more professional. In some farms agrotourism is coupled with agricultural quality products directly sold. 


\section{Rural tourism and sustainable agriculture}

For many rural communities new employment opportunities in recreation and tourism are off-setting the loss of direct employment in agriculture and other natural resource industries. Indeed rural development is now based on the environment which is considered as a valuable rural resource. Because farming occupies so much of the rural territory, its role in managing rural space and shaping the rural landscape is fundamental. The role of agriculture in providing rural amenities which can be used to increase development opportunities in rural areas is illustrated in Figure 1.

In the upper panel, marginal private cost of agriculture and the marginal social cost are expressed according to the level of intensification. This latter is measured by the simple indicator $Q$ equal to the output per hectare. The marginal social cost curve (Cms) is $U$ shaped whereas the marginal private cost curve (Cmp) is a simple increasing linear function. Consequently, there are two points of interest: $A$ and $B$ corresponding to the intensification levels $Q_{1}$ and $Q_{2}$. The shaded areas between the two curves gives the difference between positive and negative externalities produced by agriculture. This area is also shown in the lower panel. Negative externalities dominate positive ones both for low levels $\left(Q<Q_{1}\right)$ and high levels $\left(Q>Q_{2}\right)$ of intensification. Between $Q_{1}$ and $Q_{2}$ agriculture generates a net flow of amenities and can be defined as being sustainable.

\section{Figure 1. Agricultural sustainability and provision of amenities}

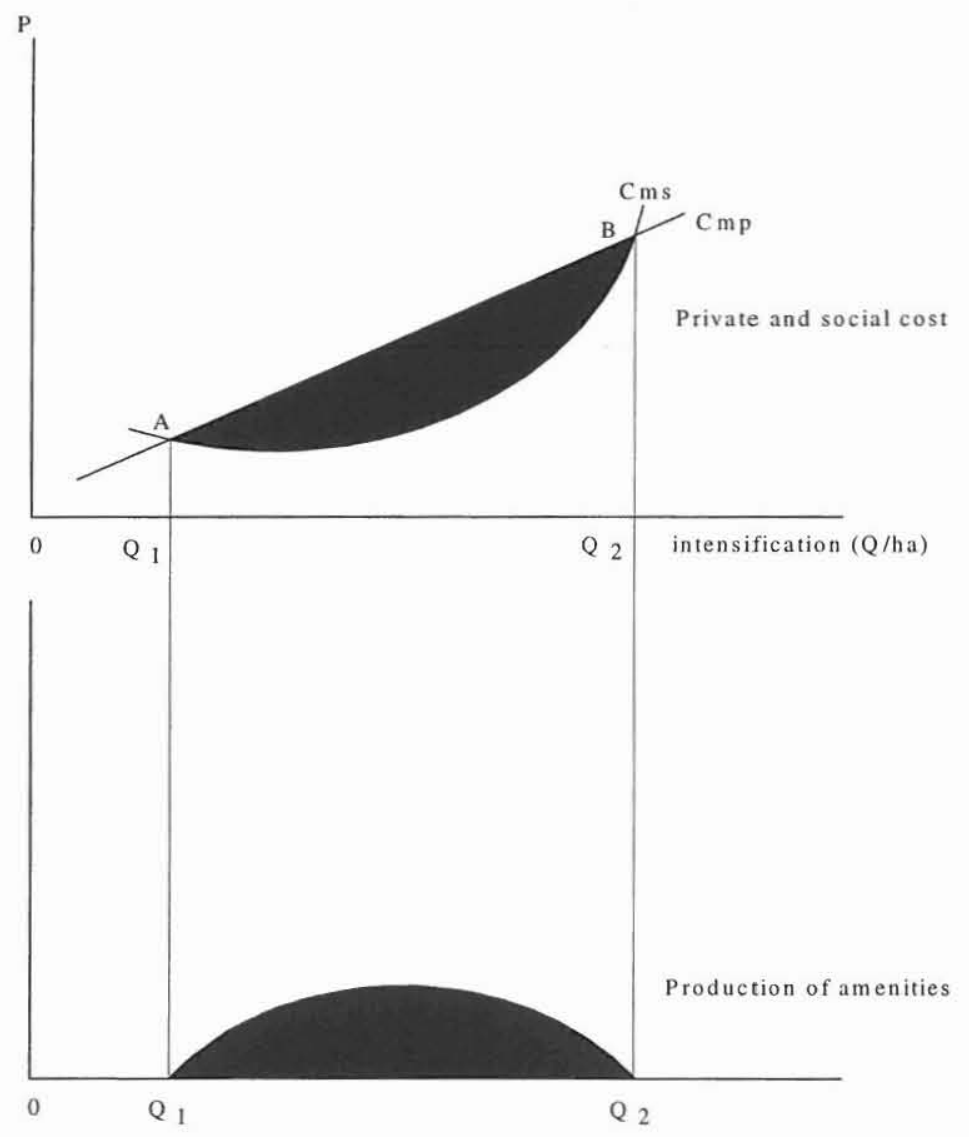

Negative externalities below $Q_{1}$ and above $Q_{2}$ arise from opposing forces. In the former case, they are due to the reduction in farming activities in the less favoured areas such as mountains. In the Alps, for instance, the abandonment of pastures and grassland areas with difficult geographic conditions has negative environmental consequences. When permanent forage crops situated in sloping zones are not mown or cut regularly, there is a high risk of erosion. Moreover, in winter the snow mantle is not stabilised and avalanches can occur. In the Mediterranean area when pastures are not grazed and revert to scrub, the risk of fires increase.

The reduction in farming activities also affects biological diversity and landscape aesthetics. After a few year of scrub invasion, its growth can block out vistas narrowing the horizon and increasing the monotony. In the 
If we now consider the medium level of intensification corresponding to the interval $Q_{1} Q_{2}$, the nature of environmental goods with regard to tourism will differ according to the region and the type of farming. The relationship between local conditions and land-use, and the resources valued by tourists can be shown graphically (see Figure 2 derived from Figure 1).

Figure 2. The relationships between type of farming and opportunities for tourism

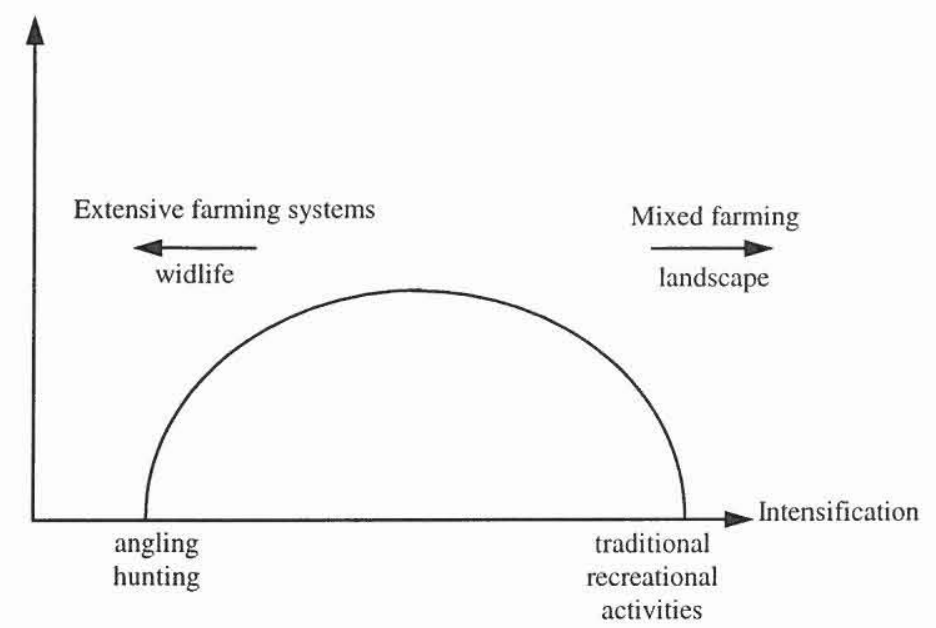

The precise shape of the curve in Figure 2 will vary according to regions and types of farming. The underlying relationship implies the existence of a strong jointness linking the production of farm commodities and the provision of environmental goods which are an input to the tourist activity. The major issue concerns the degree to which rural amenities linked to sustainability can be used to produce marketable services. Where environmental values are high the first way in which markets permit the commoditisation of rural amenities is through the sale of land and buildings for second homes. Other forms of marketing environmental products exist which are examined in the next section.

\section{General framework}

\subsection{Sustainability and rural amenities}

The close relationship between the sustainability of agriculture and rural amenities can be used as a development tool for rural areas in which they lie. These offer the whole society, mainly urban centres with a high income, a valuable service which they partially pay for through countryside tourism and other forms of commoditisation.

From an economic point of view the different amenities represent a value to some or to all individuals, just as other commodities valued through the market. The different utilities derived from amenities allow us to differentiate them according to their type, their local impact and their possible market value for agriculture. An illustration is given in Table 5 for mountainous zones. Amenities are classified according to the various values (use value and ecological value).

Concerning use value, the utility or the value people derive from the underlying amenity is either linked to the direct physical use of the corresponding amenity, or it is indirectly linked. When there is a direct use value through the existence of a "terroir"(see table 5)valuation by the market is simple. The existence of a "terroir" allows the use of "Appellation d'Origine" labels. Currently this used chiefly for wine and cheese, but nowadays it can be used for other products such as vegetables or olive oil. Concerning cheese there is a famous one in the Alps, Beaufort which is produced in a specific area with strict requirements for feeding cows and processing cheese. The higher the intrinsic quality for the "terroir", the more pronounced the price effect. In other words, " differentiation of agricultural products according to quality and origin, seems to have a series of positive consequences not only for farmers' income, but also for the environment and rural amenities" (Merlo, 1996). The quality of landscapes can also provide services which can be partially captured via agro-tourism. 
Table 5. Possible market valuation of amenities for tourist services rendered by mountain and hill farming

\begin{tabular}{|c|c|c|c|c|}
\hline & \multirow{2}{*}{$\begin{array}{l}\text { Source } \\
\text { of amenity }\end{array}$} & \multirow[t]{2}{*}{ Local impact } & \multicolumn{2}{|l|}{ Value to agriculture } \\
\hline & & & Market role & Form \\
\hline \multirow{2}{*}{$\begin{array}{l}\text { Direct use } \\
\text { value }\end{array}$} & Existence of a "terroir" & $\begin{array}{l}\text { Products entitled to a } \\
\text { special label } \\
\text { "Appellation d'Origine" }\end{array}$ & Yes, directly & $\begin{array}{l}\text { Premium prices for } \\
\text { products }\end{array}$ \\
\hline & Quality of landscapes & $\begin{array}{lr}\text { Space } & \text { management } \\
\text { special } & \text { farming } \\
\text { practices } & \end{array}$ & $\begin{array}{l}\text { Yes, partially via } \\
\text { agro-tourism, bed and } \\
\text { breakfast }\end{array}$ & $\begin{array}{l}\text { Provision of services } \\
\text { landscaping contracts }\end{array}$ \\
\hline $\begin{array}{l}\text { Indirect use } \\
\text { value }\end{array}$ & $\begin{array}{l}\text { Protection against } \\
\text { flooding and erosion }\end{array}$ & $\begin{array}{l}\text { Land maintenance } \\
\text { and favourable farm } \\
\text { practices maintenance } \\
\text { of terraces }\end{array}$ & No & $\begin{array}{l}\text { National and } \\
\text { European system } \\
\text { of aid }\end{array}$ \\
\hline \multirow{3}{*}{$\begin{array}{l}\text { Ecological } \\
\text { value }\end{array}$} & \multirow{2}{*}{$\begin{array}{l}\text { Biological diversity) } \\
\text { (fauna and flora } \\
\text { habitat richness }\end{array}$} & $\begin{array}{l}\text { Presence of particular } \\
\text { ecosystems }\end{array}$ & No & Maintenance subsidies \\
\hline & & hunting and angling & $\begin{array}{l}\text { Yes, partially } \\
\text { via tourism }\end{array}$ & $\begin{array}{l}\text { Special contracts } \\
\text { with farmers and } \\
\text { landowners }\end{array}$ \\
\hline & $\begin{array}{lr}\text { Contribution } & \text { to } \\
\text { balanced } & \text { land-use } \\
\text { planning } & \text { and } \\
\text { development } & \\
\end{array}$ & $\begin{array}{l}\text { Presence of a certain } \\
\text { agricultural population }\end{array}$ & No & $\begin{array}{l}\text { Grants to retain } \\
\text { farmers }\end{array}$ \\
\hline
\end{tabular}
* "terroir" can be defined as a circumscribed agricultural area having unique soil associated with traditional
agricultural and processing techniques.

Use value can also be indirect since sustainable agriculture using pastures and terraces in mountain areas avoids land slides, erosion with off-site damages, and flooding. The utility people derive from favourable farm practices, or more generally from the presence of a certain farm population, is linked to the produced amenities but in an indirect way. For such positive externalities there is no market. From a social point of view, the achievement of a Paretian optimum requires farmers to be compensated for the provision of these services by an amount equal to the sum of consumers' marginal utility. Theoretically this amount should be paid by the consumers who benefit from these non-market services. Compensation to offset natural handicaps is currently supplied by governments using structural measures (Directive 268/75) in by the EU. The consequence of this is that the taxpayer who pays and not the beneficiary of the services provided.

Sustainable agriculture in mountainous zones is also the source of ecological value through the prevention of depopulation in less favoured areas and the development of balanced and viable rural areas. For such value there is obviously no market. The conservation of biodiversity provides two types of amenities. The first one places emphasis on variability or heterogeneity within species, between species and ecosystems. This variability with its greater species richness maintains ecosystems of scientific interest. Genetic resources can have an option value, an existence value. On the other hand, the richness of the habitat can give marketable services when hunting, angling and bird-watching are possible. Mushroom and berry picking can also be a source of revenue for the local population.

Table 6 shows that direct or indirect remuneration of an amenity does not capture its total value. This is particularly true for landscapes. Several studies have been conducted to estimate the value of the agricultural landscape by means of contingent valuation method. Even though the policy and the spatial attributes involved differ, it is possible to compare the results. In the case of Sweden willingness to pay to maintain an open landscape for the whole country is considered (Drake, 1992). The other studies address the landscape issue at the local level (Le Goffe and Gerber, 1994; Bonnieux and Le Goffe, 1997). The British studies are related to Environmentally Sensitive Areas, or National Parks, and they consider the regional level. 
Table 6. Willingness to pay for various agricultural landscapes in Europe (in 1994 ECU)

\begin{tabular}{|c|c|c|c|}
\hline Author & Country & $\begin{array}{l}\text { Geogra- } \\
\text { phical level }\end{array}$ & Willingness to pay \\
\hline Drake, 1992 & Sweden & national & 99 per person/year \\
\hline Pruckner, 1995 & Austria & national & $0.30-0.78$ per person/day \\
\hline Garrod et al., 1994 & UK & regional & $\begin{array}{l}22.4 \mathrm{pe} \text { r hsd/year } \\
15.1 \mathrm{per} \mathrm{hsd} / \text { year }\end{array}$ \\
\hline Garrod and Willis, 1995 & U K & regional & $\begin{array}{l}35.2 \mathrm{pe} \text { r hsd/year } \\
24.9 \mathrm{per} \text { hsd/year }\end{array}$ \\
\hline Willis and Garrod, 1993 & UK & regional & (resident and visitor) \\
\hline Bateman et al., 1995 & UK & regional & $100-187 \mathrm{per}$ hsd/year \\
\hline Le Goffe and Gerber, 1994 & France & local & $28.4 \mathrm{per}$ hsd/year \\
\hline Bonnieux and Le Goffe, 1997 & France & local & $30.9 \mathrm{per}$ hsd/year \\
\hline
\end{tabular}

Table 6 indicates that for a given geographical level the annual willingness-to-pay is of the same order of magnitude. The large amount obtained by Bateman et al., 1995 is due to the specificity of the Norfolk Broads which are under threat from flooding. The change was presented to the people surveyed as irreversible resulting in a very high willingness-to-pay.

\section{Rural amenities as public goods}

Conservation of beautiful landscapes has a value, as expressed in Table 6 using the contingent valuation method, but they do not have a price on a defined market. Landscape is a public good and rural tourism only captures a limited share of its value. It is impossible to excluding some people from consuming it. Jointures of supply is another characteristic which implies that the marginal cost of letting additional people consume the commodity is zero. On the other hand an amenity such as hunting can be viewed as a private good since there is excludability and rivalness in the use of this resource. Between these extremes live the majority of goods where exclusion would be possible and where congestion causes a diminution in value at certain levels of use. Following Whitby (1990) some rural amenities are classified in terms of rivalry and excludability (Table 7).

Table 7. A classification of some rural amenities

\begin{tabular}{|l|l|l|}
\hline \multirow{2}{*}{$\begin{array}{l}\text { excludable } \\
\text { non-excludable }\end{array}$} & rival & non rival \\
\cline { 2 - 3 } & $\begin{array}{l}\text { shooting, fishing } \\
\text { foot paths and bridleways }\end{array}$ & $\begin{array}{l}\text { public monuments (castles) } \\
\text { landscapes, lakes }\end{array}$ \\
\hline
\end{tabular}

For some of the values and benefits linked to sustainable agriculture, the beneficiaries are local people. But in many cases the geographic spread of amenity benefits is important and a large share accrues to individuals living outside of the area where conservation costs are incurred, leading to «territorial spillovers ». When services are free, or not properly priced, there is a territorial externality. According to economic theory public goods and externalities are associated with market failures leading to an inefficient allocation of goods. To restore the Paretian optimality these unpriced public amenities have to be internalised. Internalisation gives an incentive to provide amenities by preserving existing ones or by promoting new ones.

With respect to territorial spillover the issue of property rights is crucial. Society grants rural people, especially farmers, implicit property rights. Indeed, the role of farmers as guardians of the countryside is firmly acknowledged. Direct payments foreseen by Regulations 2328/91 and 2078/92 are justified because farmers accept constraints on their activity which reduces the level of negative externality. These schemes can be interpreted as a reallocation of property rights, the payment being the price for purchasing or renting rights from farmers by the public authorities.

To avoid a sub-optimal level of provision of public amenities a certain number of policies are possible. According to Hodge (1993), four categories of responses exist : stimulating the supply of amenity, raising funds to fund environmental protection, regulating the levels of amenity consumption and stimulating markets for the provision of amenity. Each will be discussed below : 
- stimulating supply

These policies have tend to offer farmers positive incentives for ; 1) providing public amenities, 2) encouraging the generation of amenity benefits or, 3 ) discouraging the destruction of amenities. Theoretically, the best way to stimulate supply is to place a price on the valued attribute of amenity. As shown by Table 5 which refers to the values of agricultural landscapes, pricing is not a straightforward exercise. Pricing can be linked with a proxy variable which refers to the level of the amenity. For instance, the enhancement of a landscape amenity in a «bocage » region can be based on the restoration of hedgerows and hence the length of existing hedgrows.

In practice, agri-environmental measures associated with the traditional measures of agricultural support, are aimed to « compensate farmers for any income losses caused by reductions in output and/or increases in costs and for the part they play in improving the environment ».

- raising funds to promote the provision of environmental goods.

Funds to protect or enhance positive externalities can be obtained directly by solliciting people or other economic agents benefiting from the quality of the rural environment. This is more common in the Northern European countries than in the Mediterranean countries. There are examples in France in the field of marine ecosystems with the Cousteau foundation, or the Paul Ricard foundation where funds are given by a firm to promote environmental research.

Funds can be obtained by charging users, such as visitors to National Parks in the United States who have to pay an entrance fee. Such a policy would be very difficult to implement in France. Surveys have been carried out in a forest located on the fringe of the city of Rennes in Brittany, to measure the amenities provided to urban people visiting it. The willingness-to-pay amounts to FF 110 per household per year, but, there is a unanimous refusal to pay tolls or entry fees. However raising funds by increasing local taxation is acceptable (Bonnieux and Rainelli, 1996). Instead of entrance fees it is possible to charge for car parking.

- Regulating uses

Non-price constraints can be used to limit the pressure on fragile sites. It can be based on regulation or by making access to a site more difficult such as by removing car parking facilities. To find the financial resources to cover the cost of providing amenities requires a legal framework which sometimes leads to the modification of property rights, such as restrictions of mushroom and berry picking. The legal framework is useful to protect the «appellation d'origine» products and might be applied to an Eco-Labels policy that could promote rural amenities.

- Stimulating markets

Even if the scope for capturing the value of the direct consumption of an amenity through markets appears to be limited, there are some possibilities. Besides the «appellation d'origine products» the most extensive efforts at the commodilisation of rural space relate to the provision of leisure facilities in the countryside. The rapid growth of golf courses is a good best example. But golf courses can cause environmental damages where they require removal of earth, disrupt existing hydrological patterns and entail the draining of wetlands to create greens. In this circumstance the development of new markets based on rural amenities compete with the provision of amenities.

\section{Angling and regional development : A case study in Lower Normandy}

Suppliers of rural amenities are not adequately rewarded where there is a high proportion of non-use values attached to amenities, and where it is difficult to exclude beneficiaries and thus to charge them. With respect to outdoor recreation use values represent a large part of the amenity. According to the type of recreational activity, barriers to capture this value can exist. For example, local communities cannot charge for access to mountain paths as far as mountain climbing and walking are concerned.

On the contrary, angling represents an interesting opportunity for local communities. Among the amenities provided by fresh water, use value dominates, and exclusion of potential users is possible through licences. The economic impact of angling is significant, particularly for salmon and sea-trout as anglers generally have high income levels. This case study focuses on two categories of anglers in Lower-Normandy.

\subsection{General characteristics of anglers}

In France freshwater fishing is a widespread leisure activity. A national survey carried out in 1991 by the National Council of Fishing, the Ministry of Tourism and the Ministry of the Environment showed that 5 to 6 million people participate in this outdoor recreation. Fishermen went fishing at least five days a year, or about 3 million fishing days. Recreational fishermen in the broad sense represent about 9 percent of the population. Their 
annual expenditures is estimated at FF 6 billion corresponding to an annual budget per fisherman of FF 1300 (Jantzen, 1998).

For the great majority, fishing is an activity practised in the proximity of one's home district ( 47 percent). There is a great difference for people who are coming from other regions or from other countries. Salmon and sea-trout angling only attract a limited proportion of people, 3000 for salmon and 3300 for sea-trout. A large number of these anglers fish in Western France because of the quality of the rivers of Brittany and Lower-Normandy and because of the proximity to Paris, specially for Lower-Normandy.

A survey was conducted onsite using a detailed questionnaire reviewing anglers' characteristics, fishing experience and effort, and also expenditures. The only question for which a non-response was a significant issue, referred to income. Indeed 25 per cent of the sample refused to answer. Nevertheless it appears that the angling population is made up of middle or senior executives and professionals. Family income was much higher for people leaving outside the region, particularly for fishermen coming from Paris.

There are some differences between Salmon anglers and sea-trout anglers : the former are older and have fished for a longer time ( 15 years versus 7 years). The length of the fishing day and the number of trips during the fishing season are greater for salmon than for sea-trout anglers. This corresponds to different behaviours : salmon anglers do not hesitate to spend several days at a time catching nothing, whereas sea-trout anglers are less patient and visit the river for only a half-day. Round-trip distances are similar for both categories. Table 8 does not distinguish between both categories of anglers in terms of distance travelled.

Table 8. Distribution of the round-trip distance

\begin{tabular}{|l|l|l|l|l|l|}
\hline$<10 \mathrm{Km}$ & $10-50 \mathrm{Km}$ & $50-100 \mathrm{Km}$ & $>100 \mathrm{Km}$ & $\%$ & $\mathrm{Km}$ \\
\hline 25.2 & 37.4 & 12.0 & 25.4 & 100 & 169 \\
\hline
\end{tabular}

Table 8 shows that a quarter of sport fishermen come from distances of greater than $100 \mathrm{~km}$, while the same proportion are local residents. More than 80 per cent travel in their own car and 15 per cent share friend's or family member's car.

\section{Anglers expenditures and willingness to pay}

Basic data were obtained from onsite surveys run during the 1990 fishing season with a sample of 350 anglers. These data have been updated using the results of an another onsite survey conducted in Brittany in 1995 with a sample of 176 salmon anglers (Porcher and Brulard, 1998). Structural characteristics of the two samples of salmon anglers are very close, so it is possible to match the results.

The cost for a fishing season, including transportation costs, food, lodging, fishing and depreciation of equipment, amounted to FF 10670 for salmon anglers in 1995. For sea-trout anglers a fishing season is cheaper with a cost about 50 percent less (FF 6200 ). The costs of equipment including reels, rods and lines are similar at FF 6950 for salmon anglers and FF 6425 for sea-trout anglers. Table 9 gives more detailed information on the costs incurred by anglers for lodging, food and transportation. This is useful in assessing the total economic impact of angling on local communities.

Table 9. Lodging, food and transportation costs (FF per fisherman and per fishing season)

\begin{tabular}{|l|l|l|l|l|l|}
\hline Lodging & \multicolumn{2}{l|}{ Food } & \multicolumn{2}{l|}{ Transportation costs } \\
\hline Hotel & 275 & restaurant & 751 & round-trip & 3707 \\
\hline Camping & 88 & other & 573 & on-site costs & 534 \\
\hline Other & 222 & & & & \\
\hline
\end{tabular}

Total expenses for lodging, food and transportation reached FF 6510 per fisherman per fishing season. Transportation costs represent 60 per cent of the total. For local anglers expenses amount to FF 3726 versus F 10 000 for non-local fisherman.

At the beginning of the nineties there was a management scheme where salmon catches were restricted to four salmon per angler before June $1^{\text {st }}$ plus two after. This scheme was considered as being inconsistent since the fishing season started in mid-March and allowed for the fishing of Spring-salmon which are rare, and drastically limited the catches of grilse which are relatively abundant. Salmon anglers were asked for their opinion concerning the elimination of the quota system after June $1^{\text {st }}$. For people agreeing, a payment card was used to elicit their willingness-to-pay. The average amount equalled FF103. 
linking amenities and development. When these territorial amenities have a high use-value component local communities can capture a large part of the amenity value. This is the case for «terroirs » where existing regulations assure the quality and origin of agricultural products are identified to labels. In another way the existence of property rights for angling, through licences and strict controls, gives rise to an important form of rural tourism. The example of Lower-Normandy shows that the direct and indirect impacts of anglers' expenditures, coupled with multiplier effects, have the potential to offset economic decline in more traditional sector. This case clearly demonstrates the need for rivers of good quality (clear water, enough oxygen) suitable for sport-fishing. The potentially negative impacts of tourism arising from conflicts with local residents and overuse of environmentally sensitive sites must be taken into account. There is a need for sustainable tourism in fragile areas as well as sustainable agriculture.

\section{References}

Bateman I.J., Langford I.H., Turner R.K., Willis K.G., and Garrod G.D., 1995. Elicitation and truncation effects in contingent valuation studies. Ecological Economics 12, 161-179.

Bignall E. and Mc Cracken D., 1996. The ecological ressources of European farmland in Whitby M.C. (ed) The European environment and CAP reform policies and prospects for conservation. CAB international. Wallingford.

Bonnieux F. and Rainelli P., 1996. Amenities in wetlands and peri-urbain woodland in France. In OECD Amenities for rural development - Policy examples p.75-83.

Bonnieux F., Desaigues B., Vermersch D., 1992. France in Navrud S (ed) Prising the European environment. Scandinavian University Press : 45-64.

Bonnieux F., Le Goffe, 1997. Valuing the benefits of landscape restoration : a case study of the Cotentin in Lower-Normandy, France. Journal of Environmental Management 50, 321-333.

Boude J.P., 1991. Les effets économiques induits in Bonnieux, Boude, Guerrier, Richard. La pêche sportive du saumon et de la truite de mer en Basse-Normandie. Document CSP-INRA-ENSAR. $78 \mathrm{p}$.

Drake L., 1992. The non-market value of the Swedish agricultural Landscape. European Review Agricultural Economics 19, 351-364.

Gagey D. and Rainelli P., 1996. Intérêt de l'aide à l'agriculture de montagne. Séminaire de I'OCDE sur les avantages écologiques de l'agriculture durable, Helsinki 10-13 sept.

Garrod G.D., Willis K.G. and Saunders C.M. 1994. The benefits and costs of the Somerser levels and moors ESA. Journal of Rural Studies, 10, 131-146.

Garrod G.F. and Willis K.G., 1995. Valuing the benefits of the South Downs environmental sensitive area. Journal of Agricultural Economics 46, 160-173.

Hodge I., 1993. The contribution of amenities to rural development. Rural amenity: definition, property rights and policy mechanisms OECD C/RUR (93)14.

IFEN, 1994. L'environnement en France. Dunod édition 1994-1995. Paris.

Jantzen J.M., 1998. A national survey on freshwater fishing in France. Recreational fisheries: social, economic and management aspects (Hickley and Tompkins eds) FAO-UN Fishing News Books p.5-9. 
Le Goffe P. and Gerber P., 1994. Coûts environnementaux et bénéfices de l'implantation d'une sablière en zone périurbaine. Unpublished report, INRA, Rennes, France.

Le Goffe, 1996. Hedonioc pricing of agriculture and forestry externalities. The European Association of Environmental and Ressource Economics. $7^{\text {th }}$ conference Lisbon 27 June 27-29.

Merlo M., 1996. Commoditisation of rural amenities in Italy in OECD : Amenities for rural development. Policy examples p.85-95.

Pigram J.J., 1993. Planning for tourism in rural areas. Briding the policy implementation gap in tourism research. Critiques and challenges Pearce D. and Butter W. (eds) : 156174.

Pointereau P. and Bazile D., 1995. Arbres des champs : haies, alignements, près, vergers ou l'art du bocage. Solagro-WWF.

Porcher J.P., Brulard J., 1998. An economic analysis of salmon fishing in the Finistère departement of France. Recretational fisheries : social, economic and management aspects (Hickley and Tompkins eds) FAO-UN Fishing New Books p.200-203.

Pruckner G.J., 1995. Agricultural landscape cultivation in Austria: an application od the CVM. European Review of Agricultural Economics 22, 173-196.

Stanners P. and Bourdeau P., 1995. Europe's environment. The Dobris Assessment. European Environment Agency. Copenhaguen.

Whitby M., 1990. Multiple land use and the market for countryside goods. Journal of the Royal Agricultural Society of England (151) : 32-43.

Willis K.G. and Garrod G.D., 1993. Valuing landscape : a contingent valuation approach. Journal of Environmental Management 37, 1-22. 